\title{
Black Stork Down: Military Discourses in Bird Conservation in Malta
}

\section{Brian Campbell \& Diogo Veríssimo}

\section{Human Ecology}

An Interdisciplinary Journal

ISSN 0300-7839

Hum Ecol

DOI 10.1007/s10745-015-9724-6

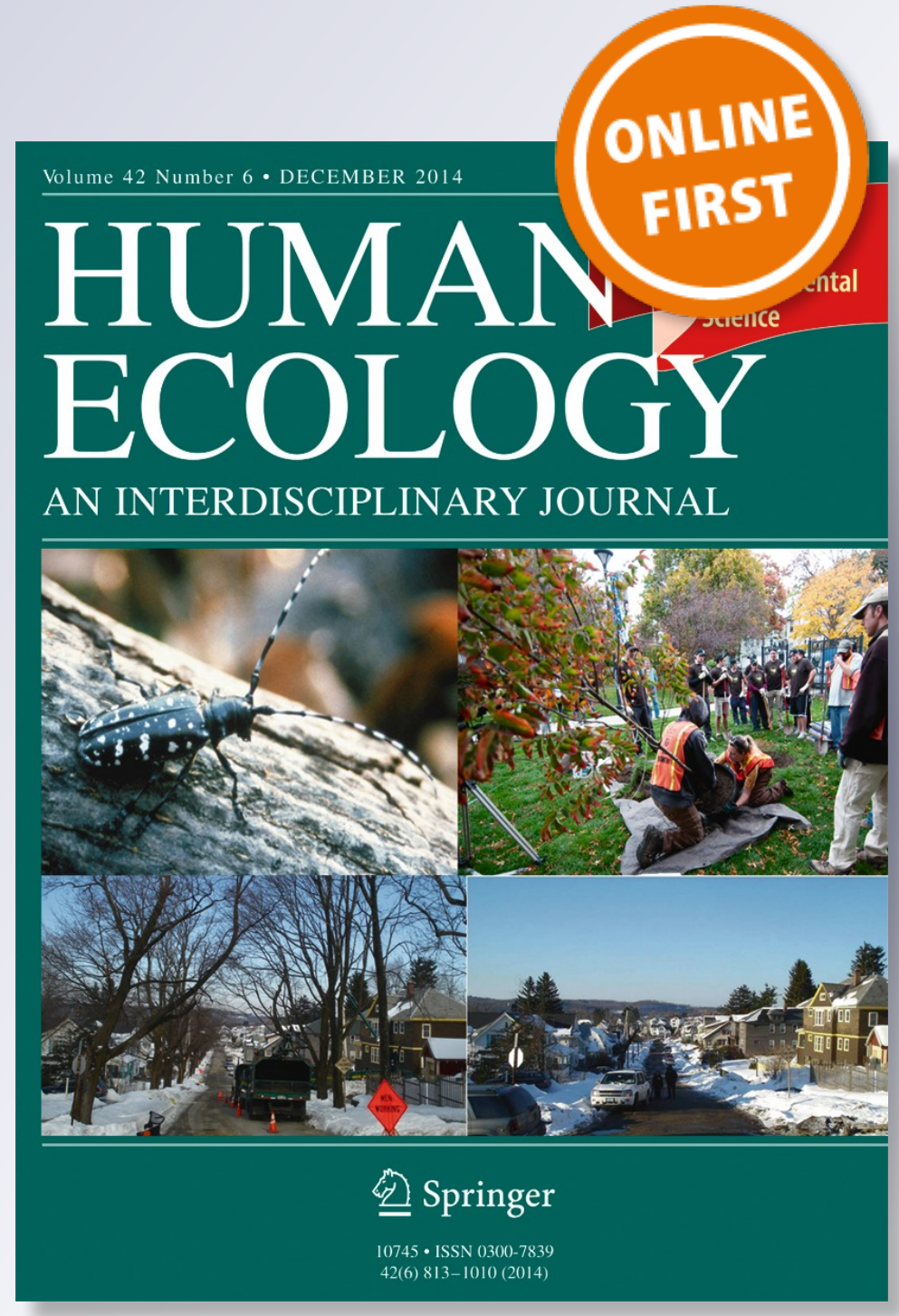

照 Springer 
Your article is protected by copyright and all rights are held exclusively by Springer Science +Business Media New York. This e-offprint is for personal use only and shall not be selfarchived in electronic repositories. If you wish to self-archive your article, please use the accepted manuscript version for posting on your own website. You may further deposit the accepted manuscript version in any repository, provided it is only made publicly available 12 months after official publication or later and provided acknowledgement is given to the original source of publication and a link is inserted to the published article on Springer's website. The link must be accompanied by the following text: "The final publication is available at link.springer.com". 


\title{
Black Stork Down: Military Discourses in Bird Conservation in Malta
}

\author{
Brian Campbell • Diogo Veríssimo
}

(C) Springer Science+Business Media New York 2015

\begin{abstract}
Tensions between Maltese hunters and bird conservation NGOs have intensified over the past decade. Conservation NGOs have become frustrated with the Maltese State for conceding to the hunter lobby and negotiating derogations from the European Union's Bird Directive. Some NGOs have recently started to organize complex field-operations where volunteers are trained to patrol the landscape, operate drones and other surveillance technologies, detect illegalities, and lead police teams to arrest poachers. We describe the sophisticated military metaphors which conservation NGOs have developed to describe, guide and legitimize their efforts to the Maltese public and their fee-paying members. We also discuss why such groups might be inclined to adopt these metaphors. Finally, we suggest that anthropological studies of discourse could help understand delicate contexts such as this where conservation NGOs, hunting associations and the State have ended in political deadlock.
\end{abstract}

Keywords Animal welfare $\cdot$ Governance $\cdot$ Malta $\cdot$ Migratory birds · Trapping

\section{Black Stork Down!}

Shortly after midday on 26 September 2013, a 'strictly protected Black Stork' was shot down in a valley in Malta (Fig. 1). A team of 'Bird Guards' - activists volunteering with the German non-governmental organisation (NGO) Committee Against Bird Slaughter (CABS) - who had been patrolling the countryside, witnessed the killing and rushed to the spot where they saw the bird fall. The hunter was nowhere to be

B. Campbell $(\bowtie) \cdot D$. Veríssimo

School of Anthropology and Conservation, University of Kent, Kent, UK

e-mail: bc324@kent.ac.uk found, but the stork, identified as a 'juvenile bird' which 'had fledged only a few months earlier, before building the strength to leave on its first migration to its winter quarters in Africa,' was 'recovered, still alive...but it died in the arms of its rescuers, moments before it was handed over to the police' (Times of Malta 2013d). This rapid response, 'the result of a strenuous and extensive search carried out by the Bird guards deployed on Gozo' at least stopped the bird from ending on 'display in an illegal collection by a trophy killer' (CABS 2013a). 'CABS', the report proudly concluded, 'will remain on Malta ... with 10 teams until the end of the month... monitoring routes and migration corridors... and bringing poachers to justice' (CABS 2013a).

A week later, 'sounds of gunfire' heralded the arrival of another six black storks. Several BirdLife Malta teams followed the birds' progress across the island. To their great relief, by evening five turned westwards flying away from the island. The remaining bird, however, circled the hills for a few moments more, before settling in the thick woodlands of Buskett for the night. BirdLife Malta mobilised all available resources to guard the bird, cordoning off the area and patrolling the surrounding woodlands for hunters. Some 'suspicious looking vehicles' were detected and the police were called for support. NGO teams, reinforced by local police squads, stood vigil over the bird, until, shortly after dawn, the stork woke up, took to the air and flew north. Gunfire broke the morning stillness and the stork crashed down into the woodland below. By the time the birdwatchers came to the scene, it was already dead (BirdLife Malta 2013b). A high-ranking BirdLife Malta official admitted to the Maltese press:।

It is extremely disappointing but no longer a shock or a surprise to hear that yet another rare bird has died at the hands of a shotgun-wielding criminal. As we guarded this bird overnight, an appalling necessity in itself, we were concerned that as soon as the bird took flight, it would be vulnerable. It is absolute disgrace that species in which 
Fig. 1 One of the black storks (Ciconia nigra) illegally shot in Malta in 2013. Copyright: International Animal Rescue Malta

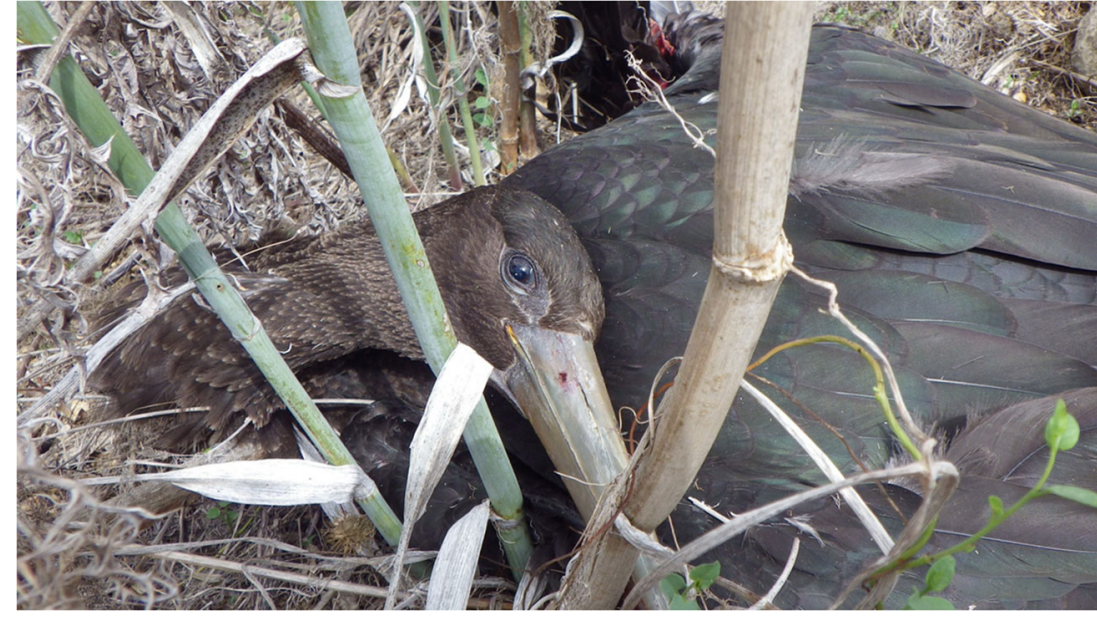

considerable conservation resources and effort are put elsewhere in Europe continue to be slaughtered in Malta's skies in the 21st Century (BirdLife Malta 2013b).
This article examines why conservation NGOs might adopt such metaphors. We conclude by suggesting that anthropological studies of discourse and metaphor could help understand delicate contexts such as this one, where conservation NGOs, hunting associations and State institutions have reached a deadlock.

\section{Introduction}

This article addresses the way bird conservation NGOs utilize military discourse to describe their activities to the public in the local press and on their websites, ${ }^{1}$ as illustrated in the above vignette. In the 'combat' against poaching in Malta, NGOs train 'recruits' and field 'veterans' (BirdLife Malta 2013c; Conlin 2009). They take the 'initiative' to 'deploy' 'guards' to 'patrol,' 'monitor' and 'survey' the landscape, 'escort' 'innocent' birds and use complex 'manoeuvres' to 'ambush' 'blood-crazed' hunters (Conlin 2009; Hirschfeld 2012).

In particular, we focus on two organisations: CABS and BirdLife Malta. During the spring and autumn hunting seasons, CABS fields around 20-35 volunteers from all over Europe (CABS 2012e, 2013b) while BirdLife Malta, a locally managed NGO with strong links to its parent-organisation BirdLife International, deploys about 50-60 volunteers from both Malta and abroad (Raine and Temuge 2008, 2009). CABS and BirdLife Malta are recognized by fellow NGOs, by the State, and by hunters, as the largest and most active NGOs on the hunting issue in Malta, providing leadership for other smaller conservation groups on the islands.

\footnotetext{
${ }^{1}$ The article is based on material published between 2008 and March 2014 in "The Times of Malta," the country's most influential newspaper, supplemented by extensive reference to press releases and reports issued by both hunting and bird conservation NGOs. We started with 2008 because in that year the European Court of Justice accused Malta of breaking terms negotiated with the EU, which encouraged NGOs to organize their quasi-military field-operations. March 2014 was the month immediately preceding the 2014 spring hunting season.

${ }^{2}$ Hunting generally refers to the shooting of migratory birds; however, rabbits are also hunted by a minority. This article focuses exclusively on the hunting of migratory birds.
}

\section{A Summary of the Maltese Hunting Scenario}

The military metaphors used by conservation NGOs cannot be appreciated without first summarizing the complex Maltese hunting scenario. Around 14,000 Maltese citizens are licensed to hunt $(k a c \dot{c} a)$, i.e., to shoot birds ${ }^{2}$ for food, sport, or as trophies and/or trap (nsib), i.e., lay elaborate traps to catch birds, which are eaten, kept as songbirds or bred to provide decoys for further traps (FKNK 2012). Hunters and trappers claim to have namra, an overwhelmingly powerful emotional force which drives them to the fields to practice their delizzju (hobby) and which could drive them to insanity, depression and even death if hunting and trapping are denied (Falzon 2008; Fenech 2010).

Which species of birds and how many of each can be hunted or trapped constitutes the core question of Malta's hunting conundrum. ${ }^{3}$ Local hunters' associations regularly pressure government to secure better deals with the European Union (EU), especially around poten-

\footnotetext{
${ }^{3}$ Estimates of the number of birds hunted per season range from an average of 150,000 to 6 million (Fenech 2010; MEPA 2010, 2011, 2012). According to official records for 2012, the most commonly hunted species was the song thrush (Turdus philomelos), at about 33,000 specimens, followed by the common starling (Sturnus vulgaris) with about 28 , 500 specimens and the skylark (Alauda arvensis) with about 15,500 specimens. These species, none of which are considered globally threatened by the International Union for the Conservation of Nature (IUCN), constituted $82 \%$ of all hunted individuals in 2012. All three species are listed in Annex II of the European Union's Bird Directive, which includes those species that can be hunted under national legislation.
} 
tial derogations ${ }^{4}$ from the European Union Birds Directive (formally known as Council Directive 2009/147/EC on the conservation of wild birds) on trapping and spring hunting. Boasting the power to determine the way their affiliated members will cast their vote in general elections, these associations have generally been successful as lobby groups.

Like many Mediterranean countries Malta receives migratory birds (tal-passa $)^{5}$ in spring on their way northwards to breed in Europe and autumn travelling southwards to warmer African climates. Hunters, however, insist that Malta lies on the fringe of birds' migratory routes, and thus gets only a fraction of the birds travelling across the Mediterranean. Hunters consider EU quotas to ruthlessly hinder what they can catch and a degree of illegal hunting - shooting/trapping of protected birds, or bagging more than allowed - continues (Lia 2011).

The situation is made more complex by the presence of several environmental NGOs, which in recent years have become increasingly vocal and active in their resistance to hunting and trapping as constituting practices that are morallyabhorrent, ecologically unsustainable and damaging to Malta's image as a quiet tourist heaven. NGOs have taken fierce stands specifically against poaching, which apart from being illegal, could also break EU derogation terms and place Malta at risk of heavy fines. NGOs accuse hunting associations of harbouring poachers and hijacking governmental politics to occupy the countryside and engage in tasteless violence. They also criticise the State (Il-Gvern) for lacking the moral fibre to take a stand against the hunting lobby, undertaking half-hearted attempts at negotiation (e.g., the Ornis Committee ${ }^{6}$ ), as well as being unable (or unwilling) to curb illegalities on the ground (BirdLife Malta 2013a).

On the assumption that an ever-increasing majority of the Maltese population shares their views, many of these NGOs have recently taken political initiative. In 2013, 11 Maltese $\mathrm{NGOs}^{7}$ together with the green political party Alternattiva

\footnotetext{
${ }^{4}$ An exemption from or relaxation of a law.

${ }^{5}$ As opposed to native, roosting birds, which are referred to as tal-post (lit. of the place).

${ }^{6}$ The Ornis committee brings together the different stakeholders around the management of bird species in Malta. It is considered unsatisfactory by both hunting and bird conservation NGOs as the number of voting government representatives greatly outweighs the number of hunting and conservation representatives combined. Moreover, it has no legislative power being solely a consultative platform.

${ }^{7}$ Ramblers Association of Malta, Nature Trust, Moviment Graffiti, International Animal Rescue Malta, Greenhouse Malta, Gaia Foundation, Friends of the Earth Malta, Flimkien ghall-Ambjent Ahjar, Din l-Art Helwa, Coalition for Animal Rights (CAR) and BirdLife Malta.

${ }^{8}$ At the time of writing (January 2014), CASH claimed to have collected the necessary number of signatures $(34,000$, or $10 \%$ of the total voting population) and is considering holding its abrogative referendum in March 2014. An abrogative referendum requires the government to enact the outcome of the vote into law with no further discussion. In an attempt to amend the Referendum Law the hunting associations have also started collecting signatures.
}

Demokratika (AD), formed the Coalition Against Spring Hunting (CASH) in an attempt to collect enough signatures ${ }^{8}$ to force a referendum that could abolish the spring hunting season. Moreover, a few organisations, such as BirdLife Malta, joined by foreign NGO groups, ${ }^{9}$ have started participating in complex and intense field operations in which volunteers are trained to watch over the Maltese countryside, aid the police to arrest poachers and, where opportunity allows, disable equipment and hinder hunters' activities (BirdLife Malta 2014).

While many hunters continue their passion, most resent the NGOs - particularly CABS (dismissed as foreigners with no right to meddle in Maltese affairs) and BirdLife (often referred to as BirdLies) - who they claim ${ }^{10}$ dominate the media, exaggerate the seriousness of the situation, fabricate stories of illegality, and depict all hunters as crazed killers, potential poachers who would kill anything under the "right conditions" (i.e., when Birdlife Malta and CABS teams are not looking). A few hunters have ceased to hunt, afraid that their 'namra' will get them into trouble with the law. Some, however, openly resist NGO operations, generally by deliberately shooting protected birds. Occasionally, scuffles with NGO members or acts of vandalism against their property (anything from slit car tyres to nailing protected birds to their doors) are reported.

\section{Drone Wars: The Maltese Countryside as a Battlefield}

Instead of the peace and quiet associated with a holiday in an otherwise exclusive rural location ... horrified visitors from other European states are almost literally 'blasted' out of bed by gunfire that begins before dawn, and goes on unrelentingly until well after the breakfast room closes (CABS 2013c).

Both CABS and BirdLife Malta field-teams, one of whose many tasks is the tallying of all gunshots heard, report that hunters have turned the Maltese countryside into a ' $a$ warzone' scaring away anyone wanting to peacefully enjoy it without fear of being shot (BirdLife Malta 2013e; Times of Malta 2013e). The implication is, of course, that this battlefield needs to be adequately and urgently surveyed, controlled and pacified. During the Autumn Raptor Camps or Spring Watch Campaigns daily reports describe the 'deployment' of

\footnotetext{
${ }^{9} \mathrm{CABS}$ and the Stiftung pro Artenvielfalt (SPA) (Foundation Pro Biodiversity)

${ }^{10}$ To gather more information on hunting in Malta, in October and November 2013 we conducted 25 semi-structured interviews and online questionnaires with the representatives of $\mathrm{CASH}$, the active members of CAR, the two main hunting organisations, the Ministry of Environment's Wild Birds Regulation Unit and the police's Administrative Law Enforcement Section.
} 
'teams,' 'squads' and 'guards,' trained to effectively 'patrol' the valleys and search for high places from which, 'armed' with a wide array of equipment, they can 'monitor' the fields below them (CABS 2013d). All 'shifts' and 'patrols' are recorded, and all events, from the mundane (e.g., changes in weather, patrol starting times) to the dramatic (e.g., evidence of illegal activity; missed or actual encounters with hunters, injuries) are logged along with their precise location and time (BirdLife Malta 2013c; CABS 2013b).

These activities are intensified when groups of particularly unusual birds pass over the archipelago. In spring of 2010, when a pair of white storks (Ciconia ciconia) visited the island, both CABS and BirdLife mobilised their volunteers for an'around-the-clock escort operation' (Times of Malta 2011). Some NGO teams were charged with following every move the graceful birds made, while other teams explored the territory over which the storks were likely to fly, trying to remove or warn the police of any hunter waiting for a shot. Regular updates were published in the local press on the status of the two birds and the organisations' efforts to ensure their safety. The situation became especially tense at sunset, when it became clear that the storks, instead of journeying north (to safety), were going to spend the night in Malta out in the open, perched on the floodlights of the island's main football stadium. Several teams were ordered to patrol an area constituting the range of a hunting rifle, effectively preventing hunters from sneaking through the darkness to fire upon the birds. Although, in the end, some pot-shots were indeed taken, the storks survived the night. The saga continued for another 2 days until the birds left, with NGO activists celebrating as they took pictures of themselves waving goodbye (Times of Malta 2011).

As described in the introductory example, escort missions can also fail. In autumn 2013, similarly, a group of 60 eagles visited the island. Excited by such a rare event, both hunters (particularly younger ones wanting to 'set up a showcase') and NGO volunteers took to the field in earnest. Despite the NGOs best efforts, only 12 eagles left Malta, and only one poacher was arrested (Times of Malta 2013a).

Furthermore, CABS and BirdLife Malta patrols cannot go everywhere. Private land cannot be entered and any transgressions are fiercely challenged. Most often, activists leave quietly. In some cases, however, and particularly when volunteers strongly suspect illegalities, they might refuse, leading to bizarre multi-lingual scuffles that inevitably end up on YouTube and are spread and parodied online.

NGO activists have developed techniques to overcome such limitations. Firstly, NGOs raise doubts as to whether hunters actually own the land they hunt upon. Secondly, NGO teams often radio any suspected illegalities to the police who are required to assess the accusations (see below). Thirdly, NGOs deploy new surveillance technologies that bypass and complicate accusations of NGO invasion of private property.
In Operation: Eye in the Sky in spring 2012, CABS used a drone to over-fly the countryside. The strategy proved to be immensely successful: not only did the police not act on hunters' claims that the drone was spying upon them, but in just a few days the drone had detected four hidden trapping sites which were subsequently raided by the police. However, after a week the drone came under fire from a hunter hidden in a field. Before the culprit could be identified or the drone flown to safety, a few more shots shattered its wing and it crashed to the ground in pieces (CABS 2012a).

In battlefield terms, however, the greatest NGO "victories" are those permanently keeping hunters away from an area. This is achieved either with the support of the State, resulting in the creation of'refuges,' 'sanctuaries,"shelters' or'reserves' where any form of hunting is forbidden, or by convincing private land-owners that hunter activity on their land is damaging to their long-term interests. It is to one such example that we now turn (Times of Malta 2013e, 2014).

\section{Vigilantes!}

Up until fairly recently, all field activities by NGOs were exclusively restricted to Malta, the largest island of the Maltese archipelago. "Malta's small sister island of Gozo has become an unsupervised playground for hunters and trappers from [both] Gozo and Malta, most of whom have the aim of trapping or shooting down anything that flies. Until CABS decided to take a hand that is!" (CABS 2013c).

The breakthrough occurred at Ta' $\dot{C}$ enc, a rural coastal area on the western side of the island dominated by steep limestone cliffs: Angered by the sound of "gunfire starting before daybreak [and] emboldened by the presence of CABS Bird guards in their distinctive T-shirts" a number of tourists staying in an expensive hotel formed a delegation and approached the owner, asking him "what action could be taken to rescue what was left of their not inexpensive holiday" (CABS 2013c). The worried owner contacted CABS leaders in Gozo and the NGO was given written and signed authorisation to "exercise domiciliary rights on behalf of the owner" (CABS 2013c).

The next day, before dawn:

Seven Bird Guards, accompanied by local supporters to cope with any language problems, assembled at the gate... the Gozo police [were to] remain in reserve [and intervene only] if aggressiveness was shown. ... After initial deployment [the guards spread out to establish] a perimeter using vehicles. [Then] ...the teams swept across the plateau on foot. Seven hunters (one clearly a trapper with a live decoy turtle dove but no nets set out) were accosted and politely asked to leave private property. Where necessary, our written accreditation was shown, and explained when the hunter was 
unable to understand legal English. One became very excitable, but was calmed down somewhat and sent away (CABS 2013c).

This conquered space also had to be defended against any counter-attacks which would inevitably follow. The next morning, therefore, bird guards:

manned the entrance gate, and conducted a visual control of vehicles entering the property. No hunters attempted entry, but several vehicles were seen to approach the entrance and turn around.

The report concludes by assuring that CABS's bird guards would continue to occupy this new acquisition:

until the end of the bird protection camp, particularly this coming weekend (27/28 April) when hunters may arrive who are not aware that the owner's rights to ban hunting and trapping are now being exercised (CABS 2013c).

The CABS report of its victory in Gozo hints at one particular idea that pervades NGO discourse in Malta. Claiming confrontation with a State unable or unwilling to clamp down on hunting despite the presumed will of the majority of the Maltese population, NGOs routinely insist they are left with no choice but to take matters in their own hands. Depicting an unrelenting enemy who cannot be reasoned with, and whose lust for blood leads him to develop cunning ways of evading the laws of the State, NGOs maintain that their only recourse is to train their volunteers in equally cunning tactics of concealment and surveillance, and beat the hunters at their own game.

In practice, conquests such as that of Ta' $\dot{C}$ enc, are rare. Despite their vigilante discourses, NGO volunteers usually find it difficult to exercise such unrestrained power without the sanction of some higher legal authority. The purging of Ta' Cenc marks an exceptional case where CABS succeeded in convincing a private owner to grant them the right to clear his property as they saw fit. Similarly, since hunters intruding in 'Nature Reserves', 'Bird Sanctuaries' automatically become poachers, they are often intercepted and expelled quickly and peacefully, often without resorting to police support (Times of Malta 2014).

Attempts to rectify illegalities without any legal mandate often meet great resistance. NGO activists accused of trespassing are frequently verbally abused and forcefully evicted. Occasionally, they sustain personal injury or have their equipment damaged. Maltese hunters, thus, "fortify" the countryside against such incursions by clearly marking the boundary of private property with crudely painted signs, sometimes decorated with fanciful, but dire, threats in English and German (Fig. 2). NGO activists have responded by developing subtler, yet more effective techniques.

\section{Operation Darth Wader: Soft-Core Vigilantism}

On 20 November 2013, CABS uploaded online a video of 'Operation Darth Wader', conducted a few days earlier (CABS 2013e). The video opens with a shot of a wellmaintained field containing a grey concrete hut. While CABS volunteers note the time, their position, and the location of the field, the camera slowly zooms in on a young man, who, clearly oblivious of the presence of the NGO activists, is casually smoking a cigarette by entrance to the hut. Panning slowly across the field, the camera focuses on various some clap nets and an electronic decoy the man had earlier set up. The camera jumps back to the man as he finishes his cigarette. He slowly walks to the clap nets, activates them, and retreats to the hut, emerging seconds later with several small cages containing live decoy birds.

Its suspicions confirmed, the CABS surveillance team splits into two: A few members, accompanied by police officers who were called on site, carefully approach the trapper, strategically using the various rubble walls and copses of trees to hide the long, difficult manoeuvre to ambush the hunter from the rear. The remainder stay in place, their camera fixed on the trapper. Their task, the video explains, is two-fold: to lure the trapper, who could be aware of their presence, into a false sense of security, and to keep the ambushers informed of any movements he might make.

Suddenly, the man reaches for his phone. A brief conversation and he rushes across the field and starts to dismantle the nets. The activists urge their companions to hurry: obviously, someone had spotted them and informed the trapper. Back in the field, the man gives up trying to secure his nets. Nervously,

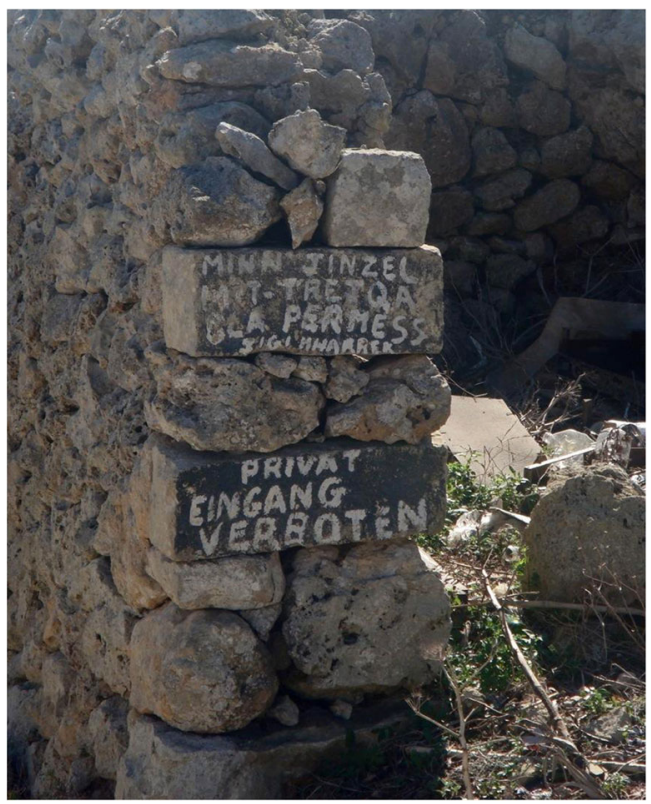

Fig. 2 Sign at the entrance of a field in the Maltese countryside. Caption Reads: [Maltese] Who uses this country lane without permission will be fined; [German]Private. No Entry. Prohibited. Copyright: Glenn Bowman 
he runs back to the hut and starts to collect his cages. He piles them on top of each other and lifts them up, but he stumbles, and the cages crash around him. He manages to tuck a few under his arm, and disappears into a copse of trees.

Moments later, the ambushers burst into the field. Some CABS activists cheer as police officers dismantle the expensive clap-nets and the electronic decoy, while others storm the hut to find cages of dotterels (Charadrius morinellus) used as decoys (Fig. 3). The video itself was eventually passed to the police, and was used to identify and arrest the trapper. He was heavily fined and his license revoked.

Successful 'Operations' such as this, often given rather grandiose names (e.g., Safe Haven, Eye in the Sky, Wings of Liberty), are regularly reported by NGOs on their own websites or in local newspapers (CABS 2013d). They not only describe their main tactics, but also reflect a form of 'soft vigilantism' that guides their actions and implies a delicate, fragile symbiosis between NGO activities and police authorities.

On the one hand, 'soft vigilantism' allows NGOs to maintain the sense of initiative on which their military rhetoric is based. Their activists are out every day patrolling, monitoring, surveying. They are the first to - and possibly the only ones who can - detect different kinds of illegalities, from the missing armbands hunters are obliged to wear, to the killing of a protected golden oriole (Oriolus oriolus) or a hoopoe (Upupa epops). NGOs also often hint that while the State claims its exclusive right to punish criminals, it is their superior tactical field experience that instructs police agents on how to effectively approach, surprise, and apprehend suspects. NGOs often celebrate their skill at mobilising what they generally consider to be an ambivalent, impassive power (CABS 2012e).
Police authority is thus described as an effective weapon, but one that nonetheless requires a skilled and determined handling.

The police, a captain of the Administrative Law Enforcement Corps (ALE) admitted one morning while his constables hauled into his office countless boxes full of stuffed birds confiscated the night before, generally accommodates this symbiosis. The ALE, extremely under-staffed, understands the value of volunteers who are willing to supplement the State's monitoring capabilities, as long as they do not directly end up in fights with local hunters.

The relationship becomes strained when police officers feel that their control over the administration of punishment is being undermined and misused. Bird conservation NGOs, the ALE captain explained, are largely concerned with the production of public relations material to secure the support of their fee-paying members. This creates obvious problems. Sometimes, for example, in their drive to show the public the gravity of the hunting situation in Malta, NGOs publish material that should have been passed to the police as criminal evidence, allowing offending hunters the opportunity to destroy incriminating evidence.

Similarly, ALE agents do not always trust NGO reports because they know that in their enthusiasm activists might see breaches of law that may not exist. For example, activists have reported to the police poachers carrying sacks of dead birds which have turned out to be farmers with sacks of potatoes, greatly embarrassing the police.

ALE agents also resent the methods NGOs use to force their constant presence in the field when volunteers spot something illegal or get into trouble - typically through anonymous calls at odd hours reporting illegal shootings,
Fig. 3 Administrative Law Enforcement agents dismantling clap-nets from an illegal trapping site. Copyright: International Animal Rescue Malta

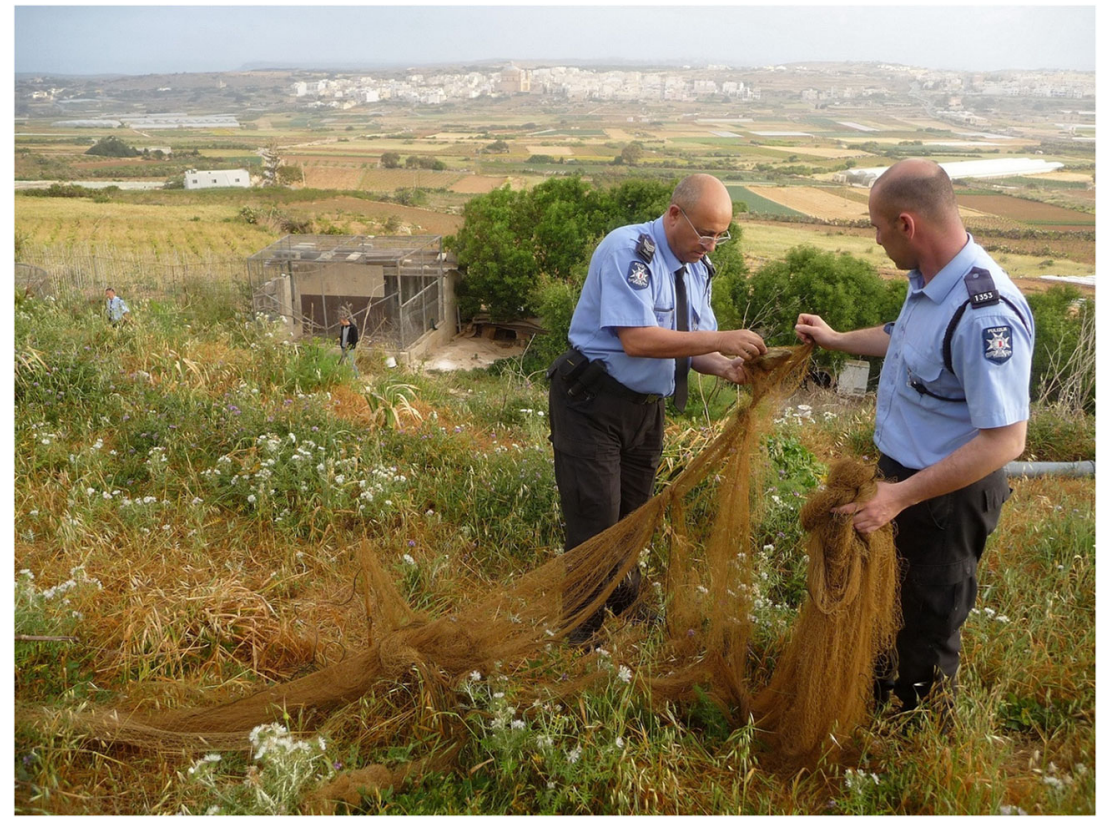


gunfire or the arrival of protected birds. Most officers respond by acquiring detailed ornithological knowledge (including the interpretation of wind patterns and weather conditions) useful in assessing the validity of NGO reports. Anonymous requests for intervention cannot be ignored. However, if police officers suspect ulterior motives, they may lower the priority of a given report, thus maintaining some sort of symbolic control over the exercise of the State's punitive power.

The police also politely refuse any NGO proposal to lecture or train officers on subjects related to migratory birds, ambush tactics, hunting culture or the Maltese environment. More explicit offers to provide police authorities with new equipment, however, are not even replied to. ${ }^{11}$

\section{Conservation Needs You: Funding, Recruitment and Training}

"Help BirdLife Malta at this very difficult time for birds migrating over Malta!" is the boldface headline on the organisation's webpage.

BirdLife Malta's ongoing campaign against illegal hunting and trapping includes operations like undercover surveillance in collaboration with the police and the organisation of two annual conservation camps: Spring Watch in April and Raptor Camp in September... You can help BirdLife Malta by joining their annual camps... and make a real difference to bird conservation" (BirdLife International 2012a).

The intensive field-activities described in this article, which require the engagement of a sizable number of volunteers over an extended period, are a real financial strain upon the often limited resources of these NGOs.

To maximise income and support they put much effort into frequently uploading reports detailing both the urgency of the situation and the efficacy of their field team operations, thus showing existing and potential supporters that their donations are making a difference at the same time as indicating the necessity for continuing financial support.

Secondly, the cost of fielding personnel can be reduced through the recruitment of volunteers. Appeals are vigorously made to individuals across Europe, but particularly the more environmentally-sensitive countries of the north. Particular emphasis is placed on the promise of adventure for volunteers (BirdLife International 2012a). There are hints that the job might involve 'some risk' and danger but phrased as

\footnotetext{
${ }^{11}$ In an official report whose formal tone barely hides a sense of frustration and disappointment, the CABS leadership lamented that they had received no reply to their offer of a drone to the police in the wake of theirs being shot down (CABS 2012b, c).
}

indicators that one is having a real impact in the hotspots of conservation in Europe. For example:

BirdLife welcomes volunteers from across Europe... [the] fight against illegal hunting of protected species... involves collecting bird migration data and reporting illegal hunting activities to local authorities. A real life spy-mission! It has been proven that BirdLife teams on the ground help deter illegal hunting... (BirdLife International 2012a).

However, new recruits have to be properly trained into a capable and well co-ordinated force (Conlin 2009). CABS outlines on its website how this is achieved:

The success of CABS is dependent on the commitment of its volunteers... Apart from a growing hard core of activists, a CABS training camp for first-timers, seasoned with a number of regulars, is held annually in October in the Brescia region of the Italian Alps. Here novices learn to move unobtrusively across rough terrain, detect the poachers' carefully concealed nets and traps, and lead Forest Police patrols to ambush positions (Conlin 2009).

\section{Casualties}

All wars leave casualties, and in the 'battle for conservation' regular losses are suffered by three distinct groups.

\section{1. 'No end in sight': Hunters and Trappers}

In 2012, CABS discovered a video on YouTube in which a group of Maltese hunters filmed themselves hunting on a boat on the Nile. A CABS report of an interview with an Egyptian bird expert opens:

Maltese hunters are crazy fanatics. They have been bird hunting in Egypt for decades, because Egypt has ... interesting looking birds compared to its neighbours ... I witnessed at first hand the indiscriminate killing of flamingos and other bird species... accompanied by cheering and laughter as the birds are hauled into the hunters' boats... and was filmed by the hunters themselves... (CABS 2012d).

The militaristic discourses employed by the NGOs simplistically cast the hunters as enemies that need to be defeated. Hunters' claims to 'namra' are indeed recognised. What is not recognised - and thus unacceptable - is the object of this overwhelming passion, which is ultimately the killing or trapping of a bird. This rejection turns 'namra' into a disturbing, almost 
psychotic quality. Hunters are routinely described using a range of colourful adjectives: 'crazy,' 'fanatical,' 'cruel,' 'merciless,' 'ruthless,' and 'blood-thirsty murderers' (Malta Today 2013; Times of Malta 2012), and as individuals who cannot be reasoned with or trusted to uphold any law or agreement. That hunters rarely kill for food but rather for the thrill of the hunt or for the macabre purpose of stuffing birds as trophies is simply further proof of their twisted nature (BirdLife International 2012a). Increasingly fashionable trips to the UK or Egypt, where hunters can indulge themselves upon better quotas and denser bird populations, are likewise seen as clear evidence of their bloodlust (CABS 2012d). Also disturbing to activists are the lengths most hunters are willing to go to in order to get their kills (Times of Malta 2013c): they are perceived as ready to defy any group or authority, bypass any patrol or perimeter, and even expose themselves in plain daylight in front of cameras if need be. In sum, hunters' incontrollable, insatiable obsession with killing is also seen as making them potential poachers. That the shooting of protected birds might be a sign of resistance, a message indicating who the real master of the land is not even considered.

Hunters are also routinely described as 'uncivilised' 'savages' and 'barbarians' (Times of Malta 2013b), failing to transition to modern ways of appreciating birds, namely photography and bird watching. In their insistence on the value of killing, moreover, they insist on privatising large sections of the countryside, even suggesting that foreigners should not be allowed to wander in rural areas (Times of Malta 2013b). They are thus seen as unaware or unwilling to accept the idea that Malta's biodiversity constitutes a common possession that ought to be enjoyed by all.

The only real remedy is education to sever and challenge a hunter's upbringing of his children before 'namra' flourishes. NGOs such as BirdLife Malta and Nature Trust, have indeed participated in such education programmes in schools across Malta (BirdLife Malta 2013c). Others, such as CABS, as we have seen, dedicate themselves to combating existing threats in the shortterm.

The jubilant celebratory tones of reports documenting the removal of yet another hunter or trapper from the scene, and exceptionally prized triumphant photos of equipment being destroyed, decoy birds liberated, and hunters arrested or ignominiously banished from their hunting territory are thus unsurprising.

\section{2. 'Life and limb': NGO activists}

With a strong southerly wind, migration from Italy began today around 14.00, with over 500 Marsh Harriers and Honey Buzzards... [some] Short-toed Eagles,
Black Kites ... [and] one Lesser Spotted Eagle (CABS 2011).

In 2011 the CABS website reported: "The hunters, as expected, showed their true colours. Numerous birds of prey came under fire in several locations .... CABS members, posted in exposed and highly visible positions, were mobbed and verbally abused from numerous jeeps and pick-ups."

Most BirdLife Malta volunteers, as well as most hunters we interviewed, claim having some sort of negative encounter with the opposite party. In many cases, these are limited to subtle, yet uncomfortable provocations - the brandishing of rifles by hunters, and constant, stifling surveillance and loud chatting by NGO teams that sometimes devolve into bouts of verbal challenges, warnings and insults. Though rare, some of these escalate into heated, swearword-heavy scuffles in which hunters and activists actually come to blows. Despite most hunters' best attempts to snatch away the activists' cameras many of these fights do end up online as proof of the hunters' aggressiveness.

Occasionally, however, such hostilities produce brutal, calculated acts of cold violence and vandalism. A CABS report recounts how:

The operations [we conduct] are not without risk for the volunteers. The reaction by hunters and poachers to the work of our teams is shown openly. Mostly, their anger is expressed in verbal abuse or slit car tyres. In Spring 2010, however, violence against conservationists escalated, and there were brutal attacks by masked men resulting in damage to rental cars and injury to CABS volunteers (CABS 2012a).

One morning, in fact:

a $50 \mathrm{~kg}$ boulder was used to smash the windscreen of a rented CABS patrol vehicle... The incident occurred in the early hours as two CABS teams, in the company of ALE officers, were investigating reports of illegal hunting and trapping.

"We can only assume that this cowardly attack is an act of revenge on part of bird poachers." The previous day, CABS Bird Guards recorded the illegal firing of some 300 shots at birds of prey... police units alerted by CABS were able to....arrest two poachers.

The deliberate attack ... is the latest in a series of acts of violence against bird conservationists on Malta ... last week the rear window of a BirdLife vehicle was shattered by a shotgun blast. A few days later, selfdeclared hunters attacked a foreign bird protection team and knocked an Italian member to the ground (Times of Malta 2010). 
Another CABS report, in which their militaristic discourse emerges clearly, reads:

Bird Guards... were victims of cowardly and brutal attacks both yesterday midday and again this morning ... five men masked with balaclava helmets set an ambush for a German bird protection team ... on vehicle patrol on a narrow country road. The men blocked the vehicle's passage and threw several heavy rocks at it, completely shattering the windows.

"One rock broke through the side window, and missed the driver's head by inches," reports [one] CABS biologist, currently co-ordinating operations on Malta. The attackers then tried to open the car doors and drag out the team members. The occupants, two Bird guards from Germany, escaped by the skin of their teeth, and were fortunate to incur only slight injuries (CABS 2010).

In rare cases NGO personnel might incur serious personal injury. Another CABS report publishes the testimony of one of its activists engaged in the production of a film entitled Emptying the Skies:

In addition to impressive scenes, which vividly present the viewer the scale and destructive power of bird killing, the film shows how British, German and Italian CABS members risk life and limb to prevent rare bird species from ending on the tables of poachers or gourmets...

[he] himself only escaped an attack by irate poachers by the skin of his teeth. Other members of the team were not so lucky, and two Italian conservationists required hospital treatment after being beaten. "I hadn't thought I would end up in a warzone" [he] remarked (CABS 2013e).

3. 'Death toll mounts as massacre continues': Birds as innocent casualties

The 'battle for conservation' is ultimately an effort to save birds, particularly protected species, from being shot or trapped by local hunters. So it follows that under the extended metaphor of conflict used by NGOs, migratory birds become innocent victims of both the relentless fury of their killers, against whom 'no species is safe' and the weakness of the State and the EU, whose yearly derogations 'cost thousands of threatened birds' lives' (BirdLife International 2012a, b). The "innocence" of these creatures constitutes the central pillar on which NGO military rhetoric is built and it is the concern for their safety that is ultimately seen as compelling and legitimising their activities in the field. The reclamation of land considered public and the elimination of an arrogant minority of hunters constitute additional, but not sufficient motives. Indeed, as one CABS member reported in an interview:

Many people think we're crazy... but the situation in the Mediterranean... is enough to make you crazy! (CABS 2013e).

Several approaches are used to depict birds as innocent victims. The first and most obvious is constant reliance on rhetoric normally reserved for the description of civilian mass killings in distant war-torn countries. These discourses emphasise the atrocious scale of Maltese hunting.

For example, one BirdLife Malta article in October 2013 headlined "Death toll mounts as eagle massacre continues" reports:

This morning, the confirmed body count of eagles shot down ... reached $12 \ldots$ Despite the presence of six BirdLife Malta teams and as many ALE units at least one Booted Eagle was shot down as it left its roost. Several others were seen carrying injuries after last night's shooting spree. This morning's second confirmed victim was a Short-toed Eagle... shot down in Gozo. ....

...follow[ing] what can only be described as a massacre yesterday evening... [Out of the 50 eagles seen flying] at least 10 are known to have been shot ... and many more targeted (BirdLife Malta 2013d).

One BirdLife Malta official described the events as

...a tragic wake-up call. We haven't seen the wanton slaughter of this many protected birds ... for a long time. It is difficult to see this as anything other than a complete catastrophe and the descriptions of the scale of the killing we have seen in the last $24 \mathrm{~h}$ as an 'isolated incident' ... [caused by] a few rogue bad apples is not consistent with reality (BirdLife Malta 2013d).

While such reports stress the scale of the killing, others focus on the brutality of the hunt itself describing in gruesome detail the wounds birds suffer when shot:

At least six of the 200-strong flock of storks were shot ... an injured stork was recovered but had to be euthanized by a vet. Another two injured storks were recorded in flight, with dangling legs and missing feathers (BirdLife International 2011).

Frequent reference is similarly made to 'birds flapping around in shock and terror', with 'shattered wings' broken in several places 'violently crashing into trees or fields.' 'Majestic' birds of prey are described with bright red bloodstains, 
labouring to stay in flight (BirdLife Malta 2008), accompanied by vivid photographs. It is common to encounter images of dead and wounded birds found in the field (Fig. 4), and carefully ordered rows of dead, tagged birds. To emphasise the innocence and vulnerability of the birds there are touching pictures of heavily injured birds 'dying in our [the rescuers'] arms' (Times of Malta 2013d) and lying gracefully on the activist's lap or in their embrace with their eyes closed seeming peacefully asleep rather than dead. Photographs of birds dead on the shores or cliffs of the island, with the sea (i.e., safety) in the background, saturate these NGO's websites. In almost all reports, Malta's protected birds are described as wanting nothing more than some temporary safe shelter before moving on to their breeding grounds in Europe in spring or to Africa in autumn.

\section{Tropes: Figurative Language and Conservation Management}

We have explored the military metaphors used by Malta's leading bird conservation NGOs to describe their experiences on the island. NGO activists publicly describe hunters as crazed murderers whose passion for hunting drives them to defy any authority and seize any opportunity to shoot innocent birds. The apparent untrustworthiness of hunters, combined with the perceived passivity of the State, at once warrants and compels NGOs to take the initiative and enter the field. This sense of urgency and injustice also legitimises the training of volunteers in military-inspired tactics that allow them to control the landscape, spot illegalities, and, at the risk of personal injury, either expel hunters or guide authorities through complex manoeuvres in order to capture poachers.

This infusion of conservation efforts with military discourses is not unique. Conservation biologists have increasingly drawn attention to the 'militarisation of conservation' (Neumann 2004; Spiegel 2008). They generally describe this as the political and economic process by which both states and NGOs come to rely on militarily trained personnel (often veterans or mercenaries with extensive combat experience) to deter, scatter, or even kill poachers, and protect natural resources to win the'wildlife wars' (Duffy 2010; Hoon 2013; Neumann 2004).

This article describes a somewhat different phenomenon. Despite the occasional online post suggesting that hunters should get a taste of their own medicine, the central aspect of the process of 'militarisation' described by conservation social scientists is absent in the Maltese case (see Duffy $2000,2010)$. The morally justified use of systematic military operations by the state or its delegates to pursue and eliminate poachers is simply not present. What we see, rather, is the use of military metaphors by NGOs to legitimise their involvement in the field and to communicate a sense of the urgency, difficulties and frustrations of protecting birds in Malta.

Metaphors are, most social scientists agree, discursive techniques. It must be noted that, in contrast to common parlance, social science does not simply equate 'discourse' with 'speech'. Rather, discourse is seen as incorporating a broader range of sign-systems that carry meaning, including spoken language, bodily gesture, art and music. These expressive techniques in turn reflect the way individuals think about the world and order it into categories (see Bourdieu 1977). Thus metaphors should not be seen solely as fancy linguistic
Fig. 4 Carcasses of migratory birds, including Bee-eaters Merops apiaster and Swifts Apus $s p$., discovered by the German NGO Committee Against Bird Slaughter on the Dwejra Lines, Malta. Copyright: International Animal Rescue Malta

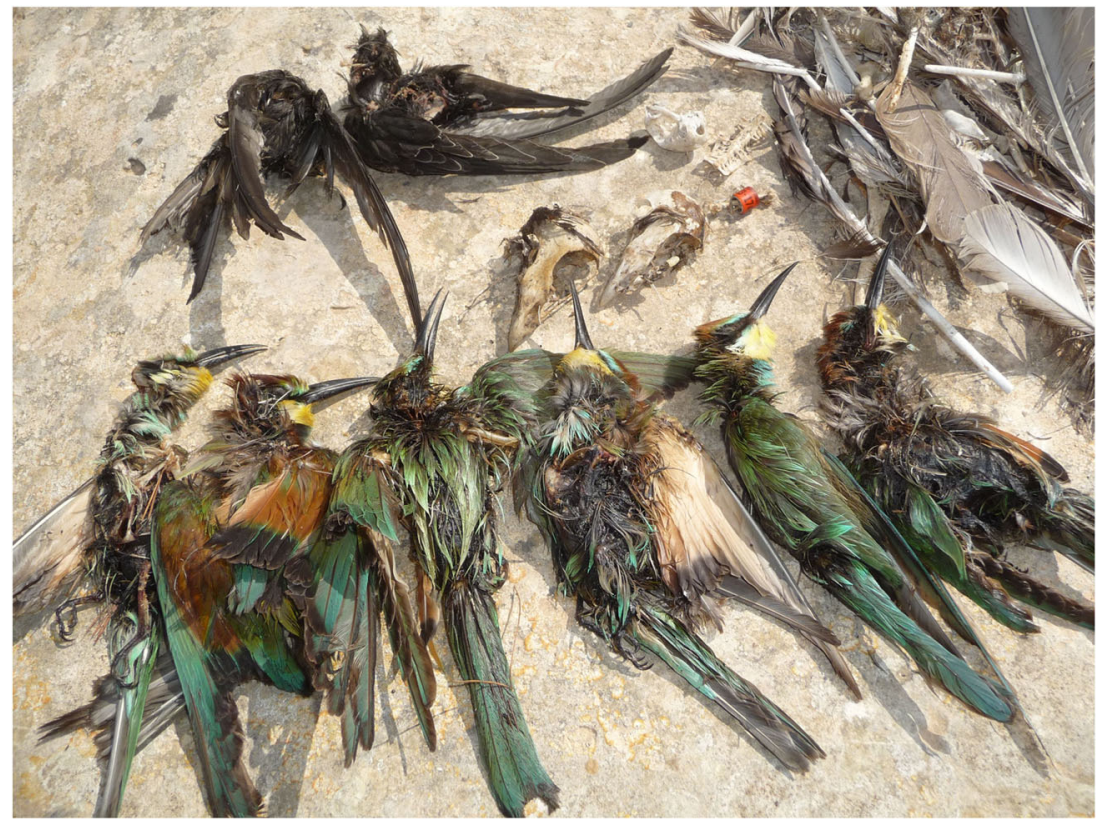


decorations, but as props that facilitate the way we grasp the world and convey our understandings to others (see BirdDavid 1992; Lakoff and Johnson 2003; Porter Poole 1986; Reddy 1993) by 1) describing one phenomenon 2) through its juxtaposition with 3) a phenomenon of similar, and wellknown characteristics (Barua 2011; Fernandez 1991; Fischer 2012; Sapir 1977; Turner 1991). In the classic examples one could have the 'heart of a lion', or 'embark on a sea of troubles.' More revealingly, Kirmayer (1993) notes how disease are often explained/understood through metaphors of war (e.g., battle against cancer), and Alverson (1994) points out that 'time' is generally described as 'money', and can be 'bought', 'wasted' or 'invented.' Metaphors, in other words, excel at describing abstract, invisible concepts (e.g., time, disease, courage, trouble) with concrete, material ones (e.g., money, war, lion, sea) .

As with any other similar independent organisation, bird conservation NGOs in Malta are constantly faced with a pressing problem: their existence depends on the continued moralpolitical support of the Maltese population and the financial contributions of their fee-paying members throughout Europe. These groups only have a limited knowledge of Maltese and European hunting laws, avian biology or ecological sustainability so that conveying the ecological, legal and political urgency for intervention in the field and explaining how the NGO is making things better can be quite challenging.

War, on the other hand, is something most people can more readily understand, and provides NGOs with the powerful explanatory tool they need. Thus, while challenges to hunters' claims to land and the sanctity of nature reserves might confuse some, the conquest and fortification of territory is easier to understand. To explain the State's hesitation and passivity, even when confronted with threats of a referendum, requires some knowledge of Maltese politics, but the depiction of the State as a weak character bullied by aggressive, blood-crazed fanatics, is immediate and powerful. Similarly, the value of getting accurate records of migratory birds and ensure their passage to their breeding grounds in Europe might be abstract, but the protection of innocents on their way home is something the public can sympathise with. The idea of being alone in a foreign land, trying to leave some impact on the big world of conservation is overwhelming, but the image of an elite strike-force, outnumbered and outgunned, cunningly striking behind enemy lines in one of the 'hotspots' of conservation lends both direction and value to NGO activities. Presenting scuffles with local hunters through reference to frustrating derogations and complex land tenure law can be somewhat counter-productive, but treating injuries as red badges of courage earned protecting innocents against brutal savages is morally neater and considerably simpler to explain.

Notions of victory and defeat, aggression and hostility, loss and martyrdom, bravery and cowardice, tactics and cunningness are, if not within the realm of experience, then at least within the grasp of imagination. In short, extended military metaphors point to a way in which the roles the NGOs play in obscure structures of power are rendered accessible - and legitimised - to their audiences and to themselves.

Metaphors, however, are more than models of explanation. First, in order to complete their juxtaposition, metaphors often resort to exaggeration: the highlighting of a particular quality of a phenomenon. Thus, to present a simple banal example, an argument could be 'defended' or 'attacked,' bringing to the fore the element of conflict where one argument seeks to nullify another through critique and counter-argument. However, in establishing such focus, other, possibly equally important qualities could be lost, hidden, ignored or played down (Larson 2005). An argument could also be 'constructed' and if 'flimsy' it might 'collapse.' It could even be 'eloquent' or 'elegant,' delivered in such as way as to make it aesthetically pleasing. Such effect might or might not constitute a deliberate strategy on part of the user of the metaphor (Lakoff 1992).

Second, metaphors can also act as blueprints - not only techniques by which reality is understood, but also 'shaped' and ultimately 'acted upon' (Kimmel 2004; Turner 1974). Keeping these simple mechanics of figurative language in mind, the Maltese case yields some interesting conclusions. Particularly, we show how in adopting war-metaphors to direct their activities, policies and goals, local bird conservation NGOs might not be contributing to breaking the deadlock that dominates the Maltese hunting scene, ending up tied in long, intensive and inefficient 'wars of attrition.'

Conservation biology is a relatively new discipline. Since its conception in the 1950s, however, its ultimate goal has been that conservation projects should strive to ensure the long-term persistence of the species and ecosystems that constitute the biological richness of a given area (Soulé 1985). This in practice means that the loss of individual members of a given specie is irrelevant, even acceptable, as long as the sustainable existence of the species and its role in the ecosystem is not put at risk (Soule 1985). The question of how many individuals can be lost from a population before there is an ecological impact marks one of the main concerns of conservation biologists, the answering of which requires the analysis of large amounts of data collected through long-term, systematic and evidence-based projects (Caughley 1994; Sutherland et al. 2004).

The long-term survival of species also depends on fragile agreements reached through often long and difficult negotiations with all relevant stakeholders. Conservation and conversation go hand-in-hand. Conservation biologists have long since learned the bitter lesson that blunders in this regard anything from by-passing local informal authorities, violating sacred sites or outlawing practices essential for survival might end up generating organised forms of resistance difficult to quell (Kissui 2008; Miquelle et al. 2005; Webb and Raffaelli 2008). Ideally, in fact, long-term stability is only 
achieved if apparently offending practices (e.g., hunting and trapping) are accommodated into a balanced and transparent socio-ecological system (Bennett et al. 2007). This, of course, means that some individuals of some species will be removed from the population.

This is where the limitations of the 'war' metaphor used by NGOs in Malta become evident. The usefulness of talking and acting as if the Maltese hunting scenario constituted a war zone has already been outlined. The metaphor, however, omits less glamorous but equally important aspects of bird conservation, chiefly conservation's dependence on negotiation and conflict resolution. Threats to biodiversity are driven by the lifestyle choices people make every day and so it is critical to understand that managing biodiversity is more about people than it is about biology (Veríssimo 2013). Thus, conservationists should adopt a discourse that does not marginalize other stakeholders. However, NGO discourse in Malta is based on the image of the bird as an innocent victim whose vulnerability compels and legitimises NGO field-activism. Effectively transmitting reports that efforts on the ground are aiding the long-term survival of a species (in itself an abstract concept) constitutes a difficult task. Images of captured, dead or liberated birds are more effective at securing volunteers, donations and overall support. However, once one concentrates on the intention of preventing cruelty to birds - no matter how much moral capital every animal shot generates - the goals of the conservation effort also shift firmly to the individual welfare of birds. Illegal hunting remains illegal, but if all forms of killing are abhorrent, and all life is inherently valuable and worth fighting for, then all hunting should, at the earliest opportunity, be phased out. Through their war-metaphors, NGOs slip from doing species conservation (which focuses on the species as a biological unit) to doing animal welfare (which focuses on the individual animal) - a different task entirely (BirdLife International 2012a; BirdLife Malta 2013a; Farnworth et al. 2013; Perry and Perry 2008). ${ }^{12}$

In the Maltese context, this focus on the welfare of individual birds shuts the door of negotiation. Under this discourse, any deal allowing hunters their share of birds becomes an automatic defeat. It is thus unsurprising that NGOs show little or no will to turn existing State institutions (e.g., the Ornis Committee) into viable spaces for negotiation, opting instead for grander projects that bypass discussion with hunters or the State (e.g., a referendum to abolish spring hunting). Similarly, the image of hunters as individuals possessed by the terrible need to shoot down birds casts them as savages who cannot be reasoned with or trusted to uphold any agreement. Again, dialogue, the ultimate pillar of conservation, is closed off. As we have seen, NGOs primarily operate by finding ways

\footnotetext{
$\overline{12}$ The ranks of the CASH coalition, in fact, are boosted by the inclusion of another coalition (Animal Rights Coalition) itself composed of over 20 animal welfare organisations.
}

to make hunting in particular spaces (e.g., nature reserves, Ta' $\dot{C}$ Cenc private property) or at specific times (e.g., spring hunting) illegal. This effectively and unambiguously turns hunters into poachers, allowing NGO activists to effectively apprehend them with the power of the State's legal enforcement agencies backing them up. In sum, while the discourses Maltese NGOs are using see no real difference between hunting and poaching (in the sense that both kill birds, and are thus equally morally repulsive), their field-tactics only work if they capitalise on the distinction as a legal one. Moreover, their moral guidelines regarding birds' lives provides them with the impetus to constantly seek ways by which more hunting practices could be legally classified as poaching, boosting their policing power in the countryside.

This article argues that the attention anthropologists give to rhetoric and discourse can help conservation biologists identify potential pitfalls in their efforts towards meaningful stakeholder engagement. Conservation scientists have increasingly pointed out that, in most cases, hunters and conservationists often have the same ultimate goal (Fenech 2010; Robinson and Redford 1994): the hunter's wish to hunt indefinitely can be compatible with the conservationist's aim to ensure the long-term survival of species - both require the sustainable, long-term existence and availability of animal species. What makes the Maltese case interesting is that many different factors have converged to create a situation where these groups come to see themselves as mutually exclusive and opposite factions with no common ground. In Malta, 'conservationists' and 'hunters' deny or forget any shared commonalities, values and aims that are the key to successful management.

The military discourses utilised by conservation NGOs in Malta contribute to this sense of mutual exclusivity. Conservation is, admittedly, a complicated undertaking, and military metaphors offer simple and effective ways in which NGOs can communicate the urgency of their efforts to their feepaying members, whose support they need to survive. On the other hand, these discourses also label hunters as untrustworthy savages, and birds as innocent victims that can only be saved through direct NGO vigilantism. We have shown that these discourses of incompatibility are neither natural nor inevitable. Rather, they are the end product of strategically depicting reality as a 'war' and then acting upon it as such.

Metaphors are powerful ways of shaping reality. But because they are in the end strategic choices, metaphors can also be abandoned or substituted with other figurative tools. One move towards breaking the deadlock dominating the Maltese scenario at the time of writing would be for NGOs to question and lay aside the military metaphors they have been using in the recent past. Alternative discourses need to be selected which are simple (easily communicable to supporters), but not simplistic (losing important distinctions on the ground). Furthermore, they should not automatically consider 
negotiation and compromise with the hunters as forms of defeat and surrender. The imperative is, therefore, to locate discourses that would morally, legally and politically isolate problematic groups and individuals, and not place under suspicion entire groups of influential stakeholders without whose support successful conservation is impossible. For example, these new discourses need to preserve the crucial difference between a 'hunter' and a 'poacher,' which is completely lost if birds are simply seen as victims that need to be protected against violence and cruelty. Only by finding ways in which bird conservation NGOs, Hunting Associations and the State can trust each other and thus engage in meaningful negotiation, can conservation become conversation, and the metaphorical black stork safely finish its hazardous journey.

\section{References}

Alverson, H. (1994). Universal Metaphors of Time in English, Mandarin, Hindi and Sesotho. John Hopkins University Press, Baltimore.

Barua, M. (2011). Mobilizing metaphors: the popular use of keystone, flagship and umbrella species concepts. Biodiversity and Conservation 20: 1427-1440.

Bennett, E. L., Blencowe, E., Brandon, K., Brown, D., Burn, R. W., Cowlishaw, G., Davies, G., Dublin, H., Fa, J. E., MilnerGulland, E. J., Robinson, J. G., Rowcliffe, J. M., Underwood, F. M., and Wilkie, D. S. (2007). Hunting for Consensus: Reconciling Bushmeat Harvest, Conservation, and Development Policy in West and Central Africa. Conservation Biology 21: 884-887.

Bird-David, N. (1992). Beyond the Hunting and Gathering Mode of Subsistence: Observations on the Nayaka and Other Modern Hunter-gatherers. Man 27(1): 19-44.

Bourdieu, P. (1977). Outline of a Theory of Practice. Cambridge University Press, Cambridge.

BirdLife International. (2011). White Storks hunted down. Available at: http://www.birdlife.org/europe-and-central-asia/news/white-storkshunted-down. Accessed 10 June 2014.

BirdLife International. (2012a). Join BirdLife Malta's Raptor Camp and make a real difference to bird conservation. Available at: http:// www.birdlife.org/europe-and-central-asia/news/join-BirdLifemalta $\%$ E2 $\% 80 \% 99$ s-raptor-camp-and-make-real-difference-bird. Accessed 10 June 2014.

BirdLife International. (2012b). Exemptions to EU law cause wildlife damage in Malta. Available at: http://www.birdlife.org/europe-andcentral-asia/news/exemptions-eu-law-cause-wildlife-damage-malta. Accessed 1 June 2014.

BirdLife Malta. (2008). 9 shot birds recovered since Raptor Camp's end. Available at: http://www.birdlifemalta.org/media/press/conservation/ view.aspx?id=185\#.Uv5eXmJ_tIp. Accessed 10 June 2014.

BirdLife Malta. (2013a). Strong rhetoric and brute manpower not enough to stop illegal killing. Press Release. Available at: http://www. birdlifemalta.org/media/press/hunting/view.aspx?id=501\#. Uu9c6z1 tw4. Accessed 10 June 2014.

BirdLife Malta. (2013b). Police and BirdLife Guard Black Storks, but One Shot - where was FKNK? Press Release: Available at: http:// www.birdlifemalta.org/media/press/hunting/view.aspx?id=498\#. Uuzdlz1_tw5. Accessed 1 June 2014.
BirdLife Malta. (2013c). Raptor Camp 2013: First impressions. Available at: http://birdlifemalta.blogspot.co.uk/2013/09/raptor-camp-2013first-impressions.html. Accessed 10 May 2014.

BirdLife Malta. (2013d). Death toll mounts as eagle massacre continues. Available at: http://www.birdlifemalta.org/view.aspx?id=434\#. UvPE4ppFDcs. Accessed 1 June 2014.

BirdLife Malta. (2013e). Spring hunting derogation not limited, not controlled and therefore not legal. Press Release. Available at: http:// www.birdlifemalta.org/media/press/hunting/view.aspx?id=470\#. Uu9i1D1 tw4. Accessed 20 May 2014.

BirdLife Malta. (2014). About Springwatch. Available at: http://www. birdlifemalta.org/Content/SpringWatch2014/storyofspringwatch/ 1210/\#.Uu9eyz1_tw5. Accessed 10 June 2014.

CABS. (2010). Brutal assault on CABS activists. Masked men throw rocks at Bird Guards vehicle. Available at http:/www.komitee.de/ en/projects/malta/camp-spring-2010/cabs-team-underattack. Accessed 15 June 2014.

CABS. (2011). Malta autumn 2011 BPC online diary. Available from http://www.komitee.de/en/actions-and-projects/malta/birdprotection-camps/autumn-bpc-2011. Accessed 10 June 2014.

CABS. (2012a). Model aircraft films bird trappers on Malta - drone shot down by hunters. Available at: http://www.komitee.de/en/actionsand-projects/malta/spring-bpc-2012/model-aircraft-films-birdtrappers. Accessed 12 June 2014.

CABS. (2012b). CABS offer 'drone' to the police - sending 32 'Bird guards' to Malta. Available at: http://www.timesofmalta.com/ articles/view/20120830/local/cabs-sending-32-bird-guards-tomalta.434991. Accessed 12 June 2014.

CABS. (2012c). Bird conservationists offer drone to police. Available at: http://www.timesofmalta.com/articles/view/20120831/local/Birdconservationists-offer-drone-to-police.435040. Accessed 16 June 2014.

CABS. (2012d). Hunting scenes in Egypt - CABS publishes private hunting video. Film shows shooting of Eagles, Vultures, Pelicans and Storks. Press Release. Available at: http://www.komitee.de/en/ actions-and-projects/malta/maltese-hunters-egypt. Accessed 10 June 2014

CABS. (2012e). Annual Report 2012. Available at: http://www.komitee. de/en/actions-and-projects/annual-reports/annual-report-2012. Accessed 22 June 2014.

CABS. (2013a). Black Stork down on Gozo. Press Release. Available at: http://www.komitee.de/en/actions-and-projects/malta/birdprotection-camps/autumn-2013-bpc. Accessed 23 June 2014.

CABS. (2013b). Annual Report 2013. Available at: http://www.komitee. de/en/actions-and-projects/annual-reports/annual-report-2013. Accessed 23 June 2014.

CABS. (2013c). CABS puts birds and tourists first: Daily baptism of fire ceases as hunters are moved on. Available at: http://www.komitee. de/en/actions-and-projects/malta/bird-protection-camps/spring-bpc2013/hunters-exodus. Accessed 21 June 2014.

CABS. (2013d). Massive Blow against illegal Trapping Available at: http://www.komitee.de/en/actions-and-projects/malta/birdprotection-camps/spring-bpc-2013/massive-blow-against-illegaltrappi. Accessed 23 June 2014.

CABS. (2013e). CABS \& SPA - Operation DARTH WADER - Action against illegal bird trapping on Malta \& Gozo / Dotterel. Available at: http://www.youtube.com/watch? $\mathrm{v}=\mathrm{u} 75 \mathrm{xmJUFt} 1 \mathrm{c}$. Accessed 21 June 2014.

Caughley, G. (1994). Directions in conservation biology. Journal of animal ecology: 215-244.

Conlin, D. (2009). CABS-Who are they? Bird's Eye View 31: 11.

Duffy, R. (2000). Killing for conservation: wildlife policy in Zimbabwe. James Currey Ltd.

Duffy, R. (2010). Nature Crime: How we're getting conservation wrong. Yale University Press.

Falzon, M. A. (2008). Flights of passion. Anthropology Today 24: 15-20. 
Farnworth, M. J., Watson, H., Adams, N. J. (2013). Understanding attitudes toward the control of nonnative wild and feral mammals: similarities and differences in the opinions of the general public, animal protectionists, and conservationists in New Zealand (Aotearoa). Journal of Applied Animal Welfare Science: 1-21.

Fenech, N. (2010). A complete guide to the birds of Malta. Midsea books, Valletta, Malta.

Fernandez, J. W. (1991). Beyond metaphor: The theory of tropes in anthropology. Stanford University Press.

Fischer, M. M. (2012). On Metaphor: Reciprocity and Immunity. Cultural Anthropology 27: 144-152.

FKNK. (2012). The facts about Maltese game-shooting and live-bird capturing. Sliema, Malta: 21.

Hirschfeld, A. (2012). Final Report Bird Protection Camp on Malta and Gozo 14 September - 6 October 2012, Bonn, Germany.

Hoon, P. (2013). Militarization of African Wildlife Conservation? Embedding of Anti-Poaching and the Hidden Role of the Botswana Defense Force Available at:http://ssrn.com/abstract= 2247182. Accessed 21 June 2014.

Kimmel, M. (2004). Metaphor Variation in cultural context: Perspectives from Anthropology. European Journal of English Studies 8(3): 275293.

Kirmayer, L. J. (1993). Healing and the Invention of Metaphor: The Effectiveness of Symbols Revisited. Culture, Medicine and Psychiatry 17: 161-195.

Kissui, B. (2008). Livestock predation by lions, leopards, spotted hyenas, and their vulnerability to retaliatory killing in the Maasai steppe, Tanzania. Animal Conservation 11: 422-432.

Larson, B. M. (2005). The war of the roses: demilitarizing invasion biology. Frontiers in Ecology and the Environment 3: 495-500.

Lia, R. (2011). An investigation of the underlying factors that lead to the shooting of protected birds in the Maltese Islands: a prerequisite for in situ conservation and reintroduction programmes. MSc Thesis, School of Oriental and African Studies (SOAS), University of London.

Lakoff, G. (1992). Metaphor and War: The Metaphor System used to Justify the War in the Gulf. In Pütz, M. (ed.), Thirty Years of Linguistic Evolution. John Benjamins, Philadelphia \& Amsterdam.

Lakoff, G., and Johnson, M. (2003). Metaphors we Live By. Chicago University Press, Chicago.

Malta Environment and Planning Authority. (2010). Carnet de Chasse. Available at: https://msdec.gov.mt/en/Documents/Downloads/ WBRU/CDC\%20report\%202010.doc. Accessed 23 June 2014.

Malta Environment and Planning Authority (2011). Carnet de Chasse. Available at: https://msdec.gov.mt/en/Documents/Downloads/ WBRU/CDC\%20report\%202011.doc. Accessed 23 June 2014.

Malta Environment and Planning Authority (2012). Carnet de Chasse. Available at: https://msdec.gov.mt/en/Documents/Downloads/ WBRU/CDC\%20report\%202012.doc. Accessed 23 June 2014.

Malta Today (2013). 'Illegal hunters get away with murder' - BirdLife. Available at: http://www.maltatoday.com.mt/en/newsdetails/news/ national/Illegal-hunters-get-away-with-murder-birdlife-20130921. Accessed 23 June 2014.

Miquelle, D. G., Nikolaev, I. G., Goodrich, J., Litvinov, B., Smirnov, E. N., and Suvorov, E. (2005). Searching for the coexistence recipe: a case study of conflicts between people and tigers in The Russian Far East. In Woodruffe, R., and Thirgood, S. (eds.), People and wildlife: conflict or co-existence: 305-322. Cambridge University Press, Cambridge.

Neumann, R. P. (2004). Moral and discursive geographies in the war for biodiversity in Africa. Political Geography 23: 813-837.

Perry, D., and Perry, G. (2008). Improving interactions between animal rights groups and conservation biologists. Conservation Biology 22: $27-35$.
Porter Poole, F. J. (1986). Metaphors and Maps: Towards Comparison in the Anthropology of Religion. Journal of the American Academy of Religion 54(3): 411-457.

Raine, A., and Temuge, T. (2008). Raptor Camp 2008 Report, BirdLife Malta. Ta'Xbiex, Malta.

Raine, A., and Temuge, T. (2009). Spring Watch 2009 Report, BirdLife Malta. Ta'Xbiex, Malta.

Reddy, M. (1993). The Conduit Metaphor. In Ortony, A. (ed.), Metaphor and Thought. Cambridge University Press, Cambridge.

Robinson, J. G., and Redford, K. H. (1994). Measuring the sustainability of hunting in tropical forests. Oryx 28: 249-256.

Sapir, D. (1977). The Anatomy of Metaphor. In Sapir, D., and Crocker, C. (eds.), The Social Use of Metaphor. University of Pennsylvania Press, Philadelphia.

Soulé, M.E. (1985). What is conservation biology. BioScience 35.

Spiegel, S. J. (2008). Deforestation: call for justice, not militarization. Nature 453: 280-280.

Sutherland, W. J., Pullin, A. S., Dolman, P. M., and Knight, T. M. (2004). The need for evidence-based conservation. Trends in Ecology \& Evolution 19: 305-308.

Times of Malta. (2010). Bird watchers find car windscreen smashed. Available at http://www.timesofmalta.com/articles/view/20100430/ local/bird-watchers-find-car-windscreensmashed.305110. Accessed 15 June 2014.

Times of Malta (2011). Storks get overnight police, BirdLife escort impressive public reaction. Available at: http://www.timesofmalta. com/articles/view/20110928/local/storks-delight-small-crowd-inmgarr.386838\#.UvO1y5pFDcs. Accessed 22 June 2014.

Times of Malta. (2012). Maltese hunters 'shooting protected birds' in Egypt. Available at: http://www.timesofmalta.com/articles/view/ 20120215/local/Maltese-hunters-shooting-protected-birds-inEgypt.406905. Accessed 22 June 2014.

Times of Malta. (2013a). Man arrested after massacre of eagles. Available at: http://www.timesofmalta.com/articles/view/20131024/local/rareeagles-shot-down-at-buskett.491630\#.Uu9nRz1_tw5. Accessed 22 June 2014

Times of Malta. (2013b). Where is Fred Flintstone? Available at: http:// www.timesofmalta.com/articles/view/20131221/opinion/Where-isFred-Flintstone-.499898. Accessed 22 June 2014.

Times of Malta. (2013c). CABS film illegal trapper in Gozo. Available at: http://www.timesofmalta.com/articles/view/20130917/local/CABS. 486567\#.Uu95Dj1 tw4. Accessed 23 June 2014.

Times of Malta. (2013d). Protected stork shot dead by hunters in San Blas. Available at: http://www.timesofmalta.com/articles/view/ 20130916/local/Protected-stork-shot-dead-by-hunters-in-San-Blas. 486339\#.UuzUVj1_tw5. Accessed 23 June 2014.

Times of Malta. (2013e). Hunters 'trying to kill' young wild flamingo. Available at: http:/www.timesofmalta.com/articles/view/20130901/ local/Hunters-trying-to-kill-young-wild-flamingo.484289. Accessed 22 June 2014

Times of Malta. (2014). Armed hunter arrested in bird sanctuary. Available at: http://www.timesofmalta.com/articles/view/ 20140128/local/armed-hunter-arrested-in-bird-sanctuary.504533\#. UvO8UZpFDcs. Accessed 23 June 2014.

Turner, T. (1991). 'We are Parrots', 'twins are birds': Play of tropes as operational structure. In Fernandez, J. W. (ed.), Beyond Metaphor: The Theory of Tropes in Anthropology. Stanford University Press, Stanford.

Turner, V. (1974). Dramas, Fields and Metaphors. Cornell University Press, Ithaca

Veríssimo, D. (2013). Influencing human behaviour: an underutilised tool for biodiversity management. Conservation Evidence 10: 29-31.

Webb, T. J., and Raffaelli, D. (2008). Conversations in conservation: revealing and dealing with language differences in environmental conflicts. Journal of Applied Ecology 45: 1198-1204. 